\title{
Stomatal parameters in nine species of Corchorus (Tiliaceae)
}

\author{
Susmita MAITY and Animesh Kumar DATTA* \\ Department of Botany, Genetics and Plant Breeding Section, University of Kalyani,Kalyani - 741235, \\ West Bengal, India. \\ *Corresponding author, E-mail: dattaanimesh@gmail.com
}

\begin{abstract}
Stomatal parameters namely stomatal size variation including aperture size (area), frequency of distribution, and conductance were studied in nine species (cultivated- C. capsularis L.- JRC 321, C. olitorius L. - JRO 524; wild - C. aestuans L. - WCIJ 088, C. fascicularis Lam. - WCIJ 150, C. pseudocapsularis L.CIM 036, C. pseudoolitorius I. and Z. - OIN 507, C. tridens L.- WCIJ 149, C. trilocularis L.- KBA 222 and C. urticaefolius W. and A.- WCIJ 070- the species were grown under uniform agro-climatic condition) of Jute in an attempt to screen drought tolerant species and genotypes demonstrating enhanced photosynthetic efficiency. Stomata of jute species are paracytic, amphistomatic and anisostomatic. Results indicated that $C$. aestuans, $C$. urticaefolius, C. trilocularis and C. pseudoolitorius were drought tolerant; while C. pseudoolitorius and $C$. fascicularis were apparently with enhanced photosynthetic efficiency. The desirable traits in wild germplasm may be used for efficient breeding and crop improvement.

(C) 2010 International Formulae Group. All rights reserved.
\end{abstract}

Keywords: Jute species, drought tolerance, photosynthetic efficiency, efficient breeding.

\section{INTRODUCTION}

Stomata are a unique biological window which effectively influences physiological activities of plants (Levitt, 1974; Berry et al., 2010; Haworth et al., 2010). Stomatal size, frequency and distribution differ significantly among different genotypes (Jones, 1979; Uprety et al., 2002; Zheng et al., 2006) as well as between leaf surfaces (Ricciardi, 1984) not withstanding the importance of stomata as a useful marker to identify genotypes (Ghosh et al., 2004). Stomatal spacing (Hazra, 1991) and aperture size (Tsuno and Sugumoto, 1981) are reported to influence photosynthetic rate positively (Medlyn et al., 2001; Xu and Baldocchi, 2003). Further, comparison of stomatal frequency between leaf surfaces is being related to drought resistance $(\mathrm{Hu}, 1989$; Vaz et al., 2010) and this may be one of the useful criteria in screening for drought tolerant genotypes (Shawesh et al., 1985; Munns et al., 2010). The present study documents stomatal features (size variation including aperture size, frequency distribution, interstomatal spacing and conductance) in nine species ( 2 cultivated: Corchorus olitorius L. var. JRO 524, and C. capsularis L. var. JRC 321- globally important fibre yielding plant species; seven wild species: $C$. aestuans L.-WCIJ 088, C. fascicularis Lam.- WCIJ 150, $C$. pseudocapsularis L.-CIM 036, C. pseudoolitorius I. and Z.-OIN 507, C. tridens L.-WCIJ 149, C. trilocularis L.-KBA 222 and 
C. urticaefolius W. and A.-WCIJ 070) of Jute (Corchorus; Family: Tiliaceae) with an objective to screen drought tolerant species and genotypes with improved photosynthetic efficiency which may be explored for efficient breeding and crop improvement. Only limited information is available regarding stomatal parameters in Jute (Ghosh et al., 2004; Maity and Datta, 2009).

\section{MATERIALS AND METHODS}

For the study of stomata, Quickfix image impression technique (Nayeem and Dalvi, 1989) was followed. The leaf prints (for each species 3 plants were scored and 3 leaves near to the apex from each plant were assessed-both surfaces) were taken at bud initiation stage. Stomatal frequency $\left(\mathrm{mm}^{-2}\right)$ and its distribution (near apex and away from mid vein) were recorded (light microscopic observation - 10x X 40x) among the species. Interstomatal distance and size $(\mu)$ of the stomata and aperture were measured. Considering that the shape of stomata to be elliptical its area was calculated as per Ghosh et al. (2004) using the formula [ $\pi / 4(\mathrm{~L} \mathrm{X} \mathrm{W})]$, where $\mathrm{L}$ and $\mathrm{W}$ are length and width of stomata respectively. Stomatal conductance was ascertained by multiplying stomatal aperture size and frequency according to Nerker et al. (1981).

\section{Statistical analysis}

To assess significant variation, if any, critical difference (0.05 probability level) following ANOVA was performed amongst the species for attributes like stomatal frequency, distribution and distance; while, student t-test $(0.05,0.01$ and 0.001 probability levels) was computed between two parameters taken at a time for a species. Correlation analysis (based on pooled data of all genotypes) considering five traits, namely stomatal frequency, size, pore area and distance along with leaf area was made for understanding interrelationship between/ among the traits $(0.05,0.01$ and 0.001 probability levels, DF 14).

\section{RESULTS}

Results of stomatal parameters (Figures 1-6) are presented in Tables 1 and 2. Stomatal frequency $\left(\mathrm{mm}^{-2}\right)$ among the Corchorus species was significantly $(\mathrm{p}<0.05$ to < 0.001) higher or lower than upper, ranging from 81.39 (C. trilocularis) to 176.43 (C. olitorius) in upper and 303.34 ( $C$. pseudocapsularis) to 719.72 (C. aestuans) in lower leaf epidermis. The estimates of stomatal frequency between the upper and lower surfaces (range: 0.21 to 0.58 ) being minimum in $C$. aestuans $(0.21), \quad C$. urticaefolius (0.25), C. trilocularis (0.26), $C$. pseudoolitorius (0.26) and C. fascicularis (0.28). Interstomatal distance among species varied from $53.3 \mu$ (C. olitorius) to $98.7 \mu(C$. pseudocapsularis) in upper and $20.6 \mu$ ( $C$. aestuans) to $44.5 \mu$ (C. capsularis and $C$. pseudoolitorius) in lower leaf surfaces. $C$. olitorius and $C$. urticaefolius in both leaf surfaces and $C$. aestuans and $C$. pseudocapsularis in lower surface were with closely spaced stomata. Stomatal frequency and interstomatal distance were negatively correlated in both upper $(\mathrm{r}=-0.56, \mathrm{p}<0.05)$ and lower $(r=-0.55, p<0.05)$ leaf surfaces.

T-test revealed both site specific (near mid vein- $C$. capsularis, $C$. olitorius and $C$. trilocularis in upper and C. fascicularis, $C$. pseudoolitorius and $C$. trilocularis in lower; away from mid vein - C. aestuans, $C$. pseudocapsularis, $C$. tridens and $C$. urticaefolius in upper and $C$. tridens and $C$. urticaefolius in lower leaf surfaces- $\mathrm{p}<0.05$ to $\mathrm{p}<0.001)$ and random (C. fascicularis and $C$. pseudoolitorius in upper, and $C$. capsularis, C. olitorius, C. aestuans and $C$. pseudocapsularis in lower- $p>0.05$ ) distribution of stomata.

Mostly (excepting C. fascicularis, $C$. pseudocapsularis and C. pseudoolitorius) stomatal area were significantly $(\mathrm{p}<0.05$ to $<$ 0.001) larger in upper than lower leaf surfaces. C. capsularis and C. olitorius (both leaf surfaces) had significantly broader stomata than the wild species. 
Table 1: Stomatal distribution in nine Jute species.

\begin{tabular}{|c|c|c|c|c|c|c|c|c|c|}
\hline \multirow[t]{3}{*}{ Genotypes } & \multicolumn{3}{|c|}{$\begin{array}{l}\text { Stomatal frequency } \\
\left(\mathrm{mm}^{-2}\right)\end{array}$} & \multicolumn{4}{|c|}{ Frequency distribution $\left(\mathrm{mm}^{-2}\right)$} & \multicolumn{2}{|c|}{$\begin{array}{l}\text { Interstomatal } \\
\text { distance }(\mu)\end{array}$} \\
\hline & \multirow[t]{2}{*}{$\mathbf{U}$} & \multirow[t]{2}{*}{$\mathbf{L}$} & \multirow[t]{2}{*}{$\bar{U} / \mathbf{L}$} & \multicolumn{2}{|c|}{$\begin{array}{c}\text { Upper } \\
\text { surface } \\
\end{array}$} & \multicolumn{2}{|c|}{$\begin{array}{l}\text { Lower } \\
\text { surface }\end{array}$} & \multirow[t]{2}{*}{$\mathbf{U}$} & \multirow[t]{2}{*}{$\mathbf{L}$} \\
\hline & & & & NMV & $\overline{A M V}$ & NMV & $\overline{\mathrm{AMV}}$ & & \\
\hline C. capsularis & 147.57 & 522.71 & 0.28 & 162.38 & 132.76 & 518.22 & 527.20 & 67.3 & 44.5 \\
\hline C. olitorius & 176.43 & 497.70 & 0.35 & 215.27 & 137.59 & 496.38 & 498.35 & 53.3 & 24.1 \\
\hline C. aestuans & 147.60 & 719.72 & 0.21 & 136.08 & 159.12 & 718.89 & 720.54 & 74.9 & 20.6 \\
\hline C. fascicularis & 89.72 & 317.10 & 0.28 & 90.42 & 89.02 & 344.80 & 289.40 & 82.6 & 43.1 \\
\hline C. pseudocapsularis & 168.92 & 303.34 & 0.58 & 131.66 & 206.19 & 305.00 & 301.67 & 98.7 & 27.2 \\
\hline C. pseudoolitorius & 90.00 & 325.87 & 0.26 & 93.26 & 86.73 & 352.86 & 298.89 & 84.5 & 44.5 \\
\hline C. tridens & 174.46 & 332.79 & 0.52 & 167.22 & 181.70 & 285.06 & 380.51 & 65.8 & 33.9 \\
\hline C. trilocularis & 81.39 & 316.52 & 0.26 & 92.82 & 69.95 & 331.14 & 301.89 & 89.6 & 29.4 \\
\hline C. urticaefolius & 170.51 & 690.59 & 0.25 & 164.58 & 176.43 & 626.73 & 754.44 & 58.2 & 23.9 \\
\hline $\mathrm{CD}$ at $5 \%$ level & 2.03 & 3.54 & & 1.81 & 2.06 & 2.89 & 3.55 & 8.12 & 6.40 \\
\hline
\end{tabular}

U- Upper leaf surface, L- Lower leaf surface, NMV- Near mid vein, AMV- Away from mid vein

Among the wild species, $C$. trilocularis had the largest stomata. Pore area (upper: $33.62 \mu^{2}$ to $93.43 \mu^{2}$; lower: $27.26 \mu^{2}$ to $\left.114.62 \mu^{2}\right)$ and total leaf area $\left(910.0 \mathrm{~mm}^{2}\right.$ $2986.70 \mathrm{~mm}^{2}$ ) varied among Corchorus spp. About $0.32 \%$ to $1.38 \%$ and $0.91 \%$ to $5.99 \%$ of area were represented by stomatal pore in upper and lower leaf surfaces respectively. Pore area was positively and significantly correlated with stomatal size (upper $\mathrm{r}=0.77$, $\mathrm{p}<0.01$; lower- $\mathrm{r}=0.87, \mathrm{p}<0.001)$ and leaf area (upper- $r=0.57, p<0.05$; lower-r $=0.67$, $\mathrm{p}<0.01)$ in both leaf surfaces and consequently stomatal size and leaf area were interrelated significantly (upper- $\mathrm{r}=0.77, \mathrm{p}<$ 0.01 ; lower- $\mathrm{r}=0.67, \mathrm{p}<0.01$ ).

Stomatal conductance was nearly 0.20 (C. pseudoolitorius) to 0.68 (C. tridens) times higher or lower than upper leaf surface. Among the species stomatal conductance $\left(\mu \mathrm{m} / \mathrm{mm}^{2}\right)$ varied from $3170.7 \quad(C$. pseudoolitorius) to 13787.5 (C. capsularis) in upper and 9071.9 (C. tridens) to 59913.0 (C. capsularis) in lower leaf surfaces.

\section{DISCUSSION}

Estimates of stomatal frequency between upper and lower leaf surfaces revealed that $C$. aestuans, $C$. urticaefolius, $C$. trilocularis, $C$. pseudoolitorius and $C$. fascicularis may be utilized as drought tolerant species. Shamsuzzaman et al. (1999) reported a drought tolerant mutant in $C$. capsularis $(\mathrm{C}-278)$ following sodium azide treatment $(12 \mathrm{mM})$, which performed well in field trial experiment, but failed to respond adequately in multilocational trials. Drought tolerant genotypes are also reported in other plant species (Munns et al., 2010; Vaz et al., 2010). In the present investigation, stomatal distribution was both sites specific and random, thereby corroborating the findings of Ghosh et al. (2004) in Tossa jute ( $C$. olitorius). 
Table 2: Stomatal area, aperture area and conductance in nine Jute species.

\begin{tabular}{|c|c|c|c|c|c|c|c|c|c|c|}
\hline \multirow[t]{2}{*}{ Genotypes } & \multirow{2}{*}{$\begin{array}{c}\text { Leaf } \\
\text { area } \\
\left(\mathrm{mm}^{2}\right)\end{array}$} & \multicolumn{2}{|c|}{$\begin{array}{c}\text { Stomatal area } \\
\left(\mu^{2}\right)\end{array}$} & \multicolumn{2}{|c|}{ Pore area $\left(\mu^{2}\right)$} & \multicolumn{2}{|c|}{$\begin{array}{l}\text { Per cent pore area } \\
\text { of total leaf area }\end{array}$} & \multicolumn{3}{|c|}{$\begin{array}{l}\text { Stomatal conductance } \\
\qquad\left(\mu^{2} \mathbf{m m}^{-2}\right)\end{array}$} \\
\hline & & $\mathbf{U}$ & $\mathbf{L}$ & $\mathbf{U}$ & $\mathbf{L}$ & $\mathbf{U}$ & $\mathbf{L}$ & $\mathbf{U}$ & $\mathbf{L}$ & $\mathbf{U} / \mathbf{L}$ \\
\hline C. capsularis & 2229.7 & 454.0 & 413.9 & 93.4 & 114.6 & 1.38 & 5.99 & 13787.5 & 59913.0 & 0.23 \\
\hline C. olitorius & 2986.7 & 404.9 & 254.1 & 65.2 & 70.3 & 1.15 & 3.50 & 11503.2 & 34988.3 & 0.33 \\
\hline C. aestuans & 910.0 & 282.6 & 164.0 & 79.6 & 54.5 & 1.18 & 3.92 & 11750.4 & 39239.1 & 0.30 \\
\hline C. fascicularis & 789.0 & 246.3 & 262.4 & 36.5 & 48.3 & 0.32 & 1.53 & 3274.8 & 15300.1 & 0.21 \\
\hline C. pseudocapsularis & 1682.3 & 272.6 & 279.2 & 71.5 & 64.8 & 1.21 & 1.97 & 12076.1 & 19650.4 & 0.61 \\
\hline C. pseudoolitorius & 935.5 & 240.3 & 260.6 & 35.2 & 47.8 & 0.32 & 1.56 & 3170.7 & 15563.6 & 0.20 \\
\hline C. tridens & 1060.4 & 166.8 & 132.2 & 35.4 & 27.3 & 0.62 & 0.91 & 6179.4 & 9071.9 & 0.68 \\
\hline C. trilocularis & 1156.4 & 346.2 & 326.1 & 57.6 & 62.0 & 0.47 & 1.96 & 4686.4 & 19608.4 & 0.24 \\
\hline C. urticaefolius & 921.4 & 221.0 & 141.4 & 33.6 & 33.5 & 0.57 & 2.31 & 5732.5 & 23134.7 & 0.25 \\
\hline
\end{tabular}



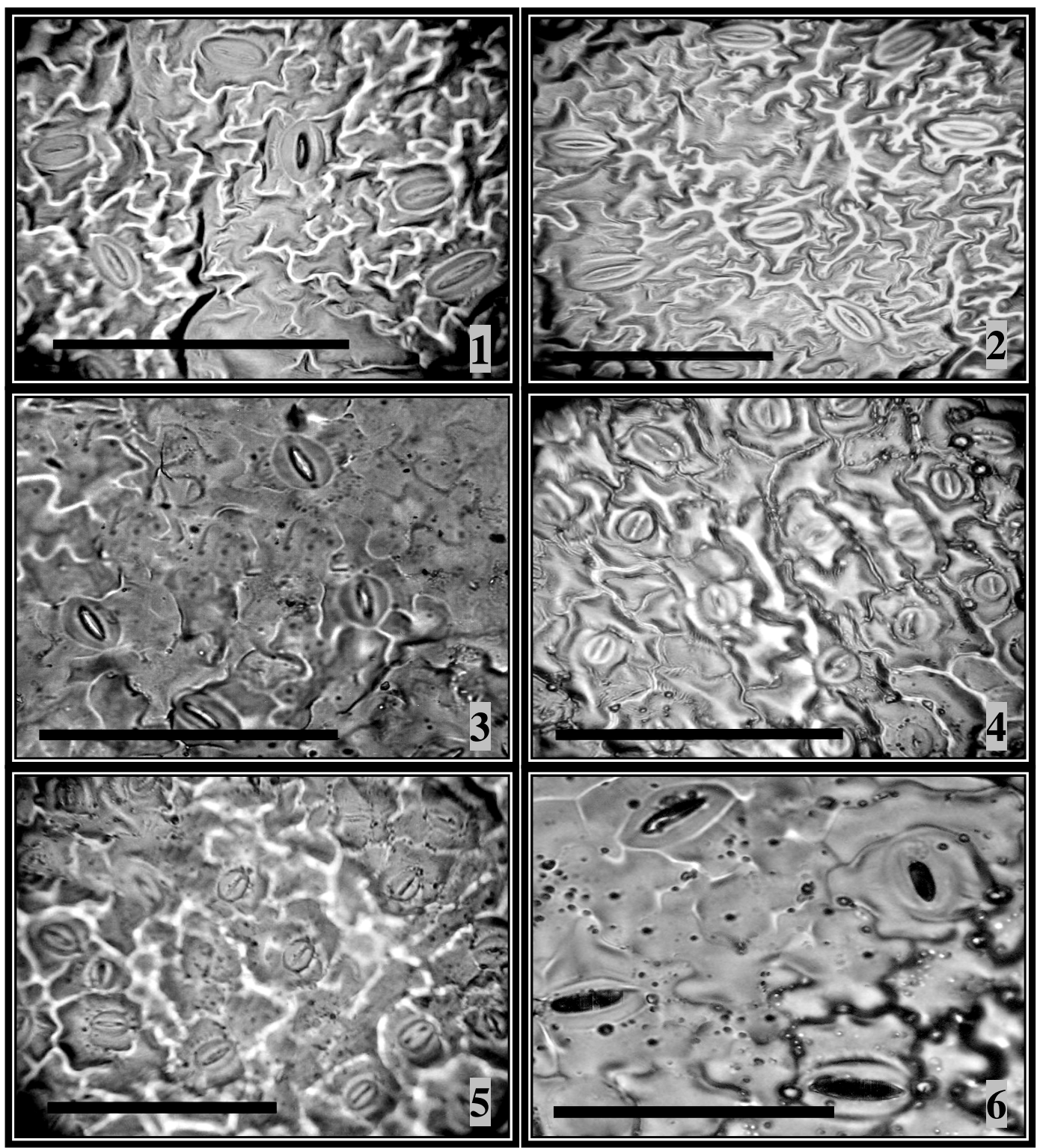

Figures: 1-6. Paracytic stomata of Corchorus spp.

1) C. pseudocapsularis. 2) C. fascicularis. 3) C. pseudoolitorius- showing relatively larger interstomatal distance. 4) $C$. urticaefolius- closely spaced small sized stomata. 5) C. tridens- showing small sized stomata. 6) C. capsularis- showing larger sized stomata. Scale bar: $100 \mu$.

However, Troughton and Donaldson (1972) documented site specific distribution of stomata in maize irrespective of the leaf surfaces. Upon comparing stomatal conductance ratio (U/L) it may be inferred that $C$. capsularis and C. fascicularis were apparently most efficient photosynthetically in relation to water stress management. Medrano et al. (2002) reported that stomatal conductance may be used as the reference parameter to reflect drought intensity. Venora and Calcagno (1991) suggested the essentiality for assessing stomatal parameters like, leaf area, number of stomata, stomatal 
area, and conductance amongst others for screening drought tolerant genotypes.

Stomatal parameters assessed amongst Corchorus spp. revealed significant variations as well as interrelationships, which may be utilized for efficient breeding and crop improvement.

\section{ACKNOWLEDGEMENTS}

The authors are thankful to Sri Arnab Bhattacharya for his kind help.

\section{REFERENCES}

Berry JA, Beerling DJ, Franks PJ. 2010. Stomata: key players in the earth system, past and present. Curr Opin Plant Biol., PMID: 20627802.

Ghosh A, Sasmal BG, Das PK. 2004. Stomatal frequency, size and genetics of tossa jute (Corchorus olitorius L.). Trop. Agric., 81: 149 - 156.

Haworth M, Heath J, McElwain JC. 2010. Differences in the response sensitivity of stomatal index to atmospheric $\mathrm{CO}_{2}$ among four genera of Cupressaceae conifers. Ann. Bot., 105: 411-418.

Hazra P. 1991. Genetic divergence, yield components and gene action in cowpea (Vigna unguiculata L. Walp.). Ph.D. thesis, B.C.K.V., West Bengal p.115.

$\mathrm{Hu}$ LC. 1989. Environmental effects on the diurnal assimilation of ${ }^{45} \mathrm{C}$ by young fruit and leaves of tomato plants. Ann. Bot., 63: $381-388$.

Jones HG. 1979. Stomatal behaviour and breeding for drought resistance. In Stress Physiology of Crop Plants. Musell H, Staples R (eds). Wiley: New York, USA; $408-428$.

Levitt J. 1974. The mechanism of stomatal movement - once more. Protoplasma, 82: 1 .

Maity S, Datta AK. 2009. Stomatal frequency, size and distribution in normal and mutant plant types of Corchorus olitorius L. (Tiliaceae). Plant Archives, 9: 943-946.
Medlyn BE, Barton CVM, Broadmeadow MSJ, Ceulemans R, De Angelis P, Forstreuter M, Freeman M, Jackson SB, Kellomäki S, Laitat E, Rey A, Roberntz $\mathrm{P}$, Sigurdsson BD, Strassemeyer J, Wang K, Curtis PS, Jarvis PG. 2001. Stomatal conductance of forest species after longterm exposure to elevated $\mathrm{CO}_{2}$ concentration: a synthesis. New Phytologist, 149: 247 - 264.

Medrano H, Escalona JM, Bota J, Gulías J, Flexas J. 2002. Regulation of photosynthesis of C3 plants in response to progressive drought: stomatal conductance as a reference parameter. Ann. Bot., 89: 895-905.

Munns R, James RA, Sirault XR, Furbank RT, Jones HG. 2010. New phenotyping methods for screening wheat and barley for beneficial responses to water deficit. J Exp Bot., PMID: 20605897.

Nayeem KA, Dalvi DG. 1989. A rapid technique for obtaining leaf prints for stomatal count with fevical. Curr. Sci., 58: $640-641$.

Nerker YS, Wilson D, Lawes DA. 1981. Genetic variation in stomatal characteristics and behavior (water use and growth in five Vicia faba) genotypes under contrasting Soil moisture regimes. Euphytica, 30: 335 - 345.

Ricciardi L. 1984. Plant breeding for resistance to drought II. Relationships between stomatal and agronomic traits in Vicia faba L. genotypes. Agric. Meditteranea, 119: 424-434.

Shamsuzzaman KM, Saha CS, Bhuya AD, Azad MAK. 1999. Development of a new jute $(C . \quad$ capsularis $)$ variety 'BINADESHIPAT-2' through sodium azide mutagenesis. Mut. Bred. Newsl., 44: 9-10.

Shawesh GA, Voigt RL, Dobreng AK. 1985. Stomatal frequency and distribution in drought tolerant and drought susceptible S. bicolor L. Moench genotypes grown under moisture stress and non-stress. Sorghum Newsl., 28: 123-125. 
Thoughton J, Donaldson LA.1972. Probing Plant Science. McGraw-Hill Book Company: New York, USA.

Tsuno Y, Sugumoto H. 1981. The relationship between stomatal aperture using the infiltration method and photosynthetic rate in some crops. Bull. Fac. Agric. Tottori Univ., 33: 126-132.

Uprety DC, Dwivedi N, Jain V, Mohan R. 2002. Effect of elevated carbon dioxide concentration on the stomatal parameters of rice cultivars. Photosynthetica, 40: 315-319.

Vaz M, Pereira JS, Gazarini LC, David TS, David JS, Rodrigues A, Maroco J, Chaves MM. 2010. Drought-induced photosynthetic inhibition and autumn recovery in two Mediterranean oak species (Quercus ilex and Quercus suber). Tree Physiol., 30: 946-956.

Venora G, Calcagno F. 1991. Study of stomatal parameters for selection of drought resistant varieties in Triticum durum DESF. Euphytica, 57: 275-283.

$\mathrm{Xu} \mathrm{L}$, Baldocchi DD. 2003. Seasonal trends in photosynthetic parameters and stomatal conductance of blue oak (Quercus douglasii) under prolonged summer drought and high temperature. Tree Physiol., 23: 865-877.

Zheng SX, Shangguanab ZP, Xue QW. 2006. Changes of stomatal parameters of four typical species in the Loess Plateau of China over the last. Acta Agriculturae Scandinavica, Section B - Pl. Soil Sc., 56: 284- 291. 